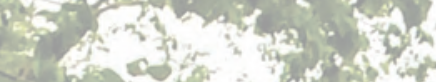

Prepared in cooperation with the Massachusetts Department of Environmental Protection

\title{
Methods Used to Estimate Daily Streamflow and Water Availability in the Massachusetts Sustainable-Yield Estimator Version 2.0
}

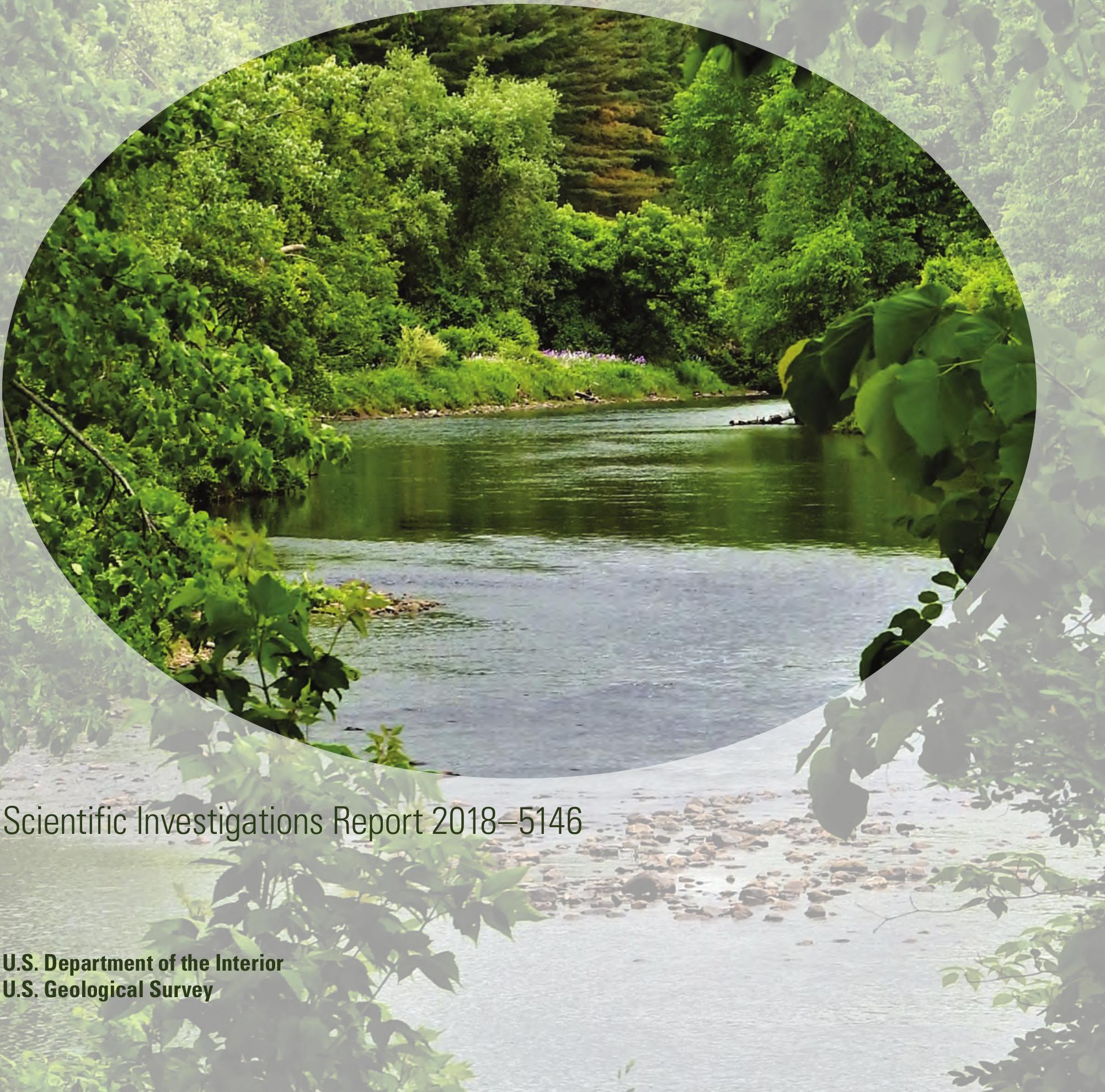


Cover. The Housatonic River near Lee, Massachusetts. Photograph by Tracey Thayer, used with permission. 


\section{Methods Used to Estimate Daily \\ Streamflow and Water Availability in the Massachusetts Sustainable-Yield Estimator Version 2.0}

By Sara B. Levin and Gregory E. Granato

Prepared in cooperation with the

Massachusetts Department of Environmental Protection

Scientific Investigations Report 2018-5146 


\title{
U.S. Department of the Interior \\ RYAN K. ZINKE, Secretary
}

\author{
U.S. Geological Survey \\ James F. Reilly II, Director
}

U.S. Geological Survey, Reston, Virginia: 2018

For more information on the USGS - the Federal source for science about the Earth, its natural and living resources, natural hazards, and the environment-visit https://www.usgs.gov or call 1-888-ASK-USGS.

For an overview of USGS information products, including maps, imagery, and publications,

visit https://store.usgs.gov.

Any use of trade, firm, or product names is for descriptive purposes only and does not imply endorsement by the U.S. Government.

Although this information product, for the most part, is in the public domain, it also may contain copyrighted materials as noted in the text. Permission to reproduce copyrighted items must be secured from the copyright owner.

Suggested citation:

Levin, S.B., and Granato, G.E., 2018, Methods used to estimate daily streamflow and water availability in the Massachusetts Sustainable-Yield Estimator version 2.0: U.S. Geological Survey Scientific Investigations Report 2018-5146, 16 p., https://doi.org/10.3133/sir20185146.

ISSN 2328-0328 (online) 


\section{Acknowledgments}

The authors thank Richard Friend and Julie Butler of the Massachusetts Department of Environmental Protection for their help in providing water-use data and their reviews of the report and software application. The authors also thank several U.S. Geological Survey colleagues: Tomas Smieszek for compiling, georeferencing, and error-checking the water-use data, Jeremy Newson for incorporating water-use data into the StreamStats web application, Gardner Bent, Scott Olson, and Marla Stuckey for their technical reviews of this report and software tool, and Rebekah Davis for her editorial review of this report. 



\section{Contents}

Acknowledgments ……...................................................................................................................

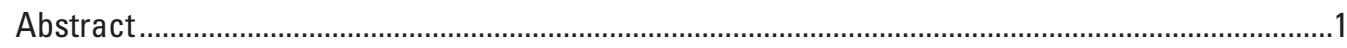

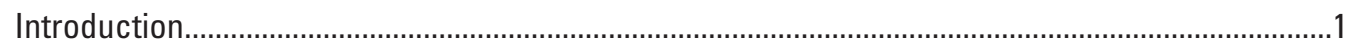

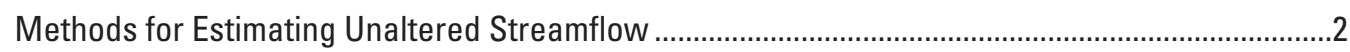

Refinements of Previously Published Methods .....................................................................

Uncertainty of Estimated Unaltered Streamflow.....................................................................

Estimation of Water-Use-Adjusted Daily Streamflow..................................................................10

Estimating Streamflow Alteration From Groundwater Withdrawals or Discharges ...............12

Calculation of Sustainable Yield Using the Massachusetts Sustainable-Yield Estimator

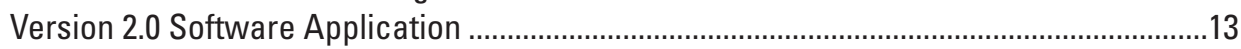

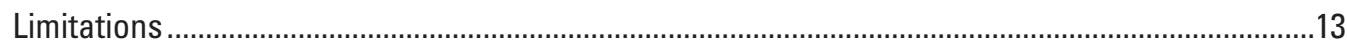

Summary

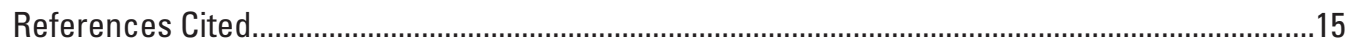

\section{Figures}

1. Map showing reference gages used in the Massachusetts Sustainable-Yield Estimator development and application

2. Graph showing streamflow estimated by the Massachusetts Sustainable Yield Estimator (MA SYE) for an ungaged basin that resulted in a non-monotonic flow duration curve and the correction added by the MA SYE version 2.0.

3. Graphs showing gaged (observed) streamflows and estimated streamflows for $A$, the lower part and $B$, upper part of the estimated daily flow duration curve for

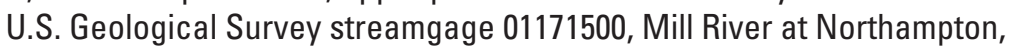
Massachusetts.

4. Schematic diagram showing the process used to compute prediction intervals for daily and monthly unaltered streamflow estimated by the Massachusetts Sustainable-Yield Estimator version 2.0.

5. Boxplots showing coverage ratios for prediction intervals for monthly average and monthly median streamflow time series simulated by the Massachusetts Sustainable-Yield Estimator version 2.0.

6. Graphs showing $A$, the median of the monthly median streamflow for estimated and gaged streamflow at 66 U.S. Geological Survey streamgages used as reference gages in the Massachusetts Sustainable-Yield Estimator version 2.0 and $B$, boxplots of the percent error of estimates of median of the monthly median streamflow

7. Map showing groundwater and surface-water withdrawal and wastewater discharge locations used in the Massachusetts Sustainable-Yield Estimator version 2.0

8. Graph showing average monthly water usage as a percentage of the annual total for six water-use categories used in the Massachusetts Sustainable-Yield Estimator version 2.0 


\section{Tables}

1. Explanatory variables and regression coefficients used to predict streamflow quantiles at ungaged, unaltered basins in the Massachusetts Sustainable Yield Estimator

2. Regression coefficients of recursive regression equations used to predict streamflows at 11 exceedance probabilities in the Massachusetts Sustainable Yield Estimator.

\section{Conversion Factors}

U.S. customary units to International System of Units

\begin{tabular}{lcl}
\hline \multicolumn{1}{c}{ Multiply } & By & \multicolumn{1}{c}{ To obtain } \\
\hline & Length & \\
\hline mile $(\mathrm{mi})$ & 1.609 & kilometer $(\mathrm{km})$ \\
\hline & Flow rate & \\
\hline cubic foot per second $\left(\mathrm{ft}^{3} / \mathrm{s}\right)$ & 0.02832 & cubic meter per second $\left(\mathrm{m}^{3} / \mathrm{s}\right)$ \\
gallon per day $(\mathrm{gal} / \mathrm{d})$ & 0.003785 & cubic meter per day $\left(\mathrm{m}^{3} / \mathrm{d}\right)$ \\
\hline
\end{tabular}

\section{Datum}

Horizontal coordinate information is referenced to the North American Datum of 1983 (NAD 83).

Elevation, as used in this report, refers to distance above the vertical datum.

\section{Abbreviations}

FDC flow duration curve

MA SYE Massachusetts Sustainable Yield Estimator

RG reference gage

v1 version 1.0

v2 version 2.0 


\title{
Methods Used to Estimate Daily Streamflow and Water Availability in the Massachusetts Sustainable-Yield Estimator Version 2.0
}

\author{
By Sara B. Levin and Gregory E. Granato
}

\begin{abstract}
The Massachusetts Sustainable-Yield Estimator is a decision support tool that provides estimates of daily unaltered streamflow, water-use-adjusted streamflow, and water availability for ungaged, user-defined basins in Massachusetts. Daily streamflow at the ungaged site is estimated for unaltered (no water use) and water-use scenarios. The procedure for estimating streamflow was developed previously and has been implemented with minor changes and updated water-use data in version 2.0 of the Massachusetts Sustainable-Yield Estimator. Unaltered streamflow at selected exceedance probabilities is estimated by previously published regression equations. Streamflow is interpolated between the regressed quantiles to produce a continuous flow duration curve. A daily streamflow time series is produced for the ungaged site by relating the estimated flow duration curve at the ungaged site to a flow duration curve at a gaged reference site and then transferring the dates from the reference site to the ungaged site.

Minor refinements were made to the previously published methods to estimate unaltered and water-use-adjusted streamflow, including a procedure to enforce the monotonic structure of the regression-based unaltered flow quantiles, improvements to the interpolation method used for computing the estimated flow duration curve, and updates to the methods used to compute time-lagged stream alterations from groundwater pumping or discharges. Additionally, a procedure was developed to estimate prediction intervals for daily and monthly unregulated streamflow time series at an ungaged site.

The Massachusetts Sustainable-Yield Estimator computes water-use-adjusted streamflow using water-use data provided by the Massachusetts Department of Environmental Protection. Available water-use data included monthly withdrawal and wastewater discharge volumes from 2010 to 2014 for surface-water and groundwater sources. Water-use-adjusted streamflow represents the potential effect of current water use on natural streamflow in the basin over the range of historical hydrologic conditions. Georeferenced water withdrawal and discharge volumes were incorporated into the Massachusetts StreamStats web application for use in version 2.0 of
\end{abstract}

the Massachusetts Sustainable-Yield Estimator. To compute water-use-adjusted streamflow, mean daily withdrawals and discharges within a user-defined basin are subtracted and added to the unaltered time series, respectively. Surface-water volumes are applied directly to the equation. Time-lagged streamflow alterations from groundwater withdrawal or wastewater discharge sources are estimated by using a responsecoefficient method developed from results of previously published, calibrated groundwater models in Massachusetts.

The Massachusetts Sustainable-Yield Estimator was updated to version 2.0 to improve software stability and usability. The version 2.0 software application was developed in Microsoft Access with a graphical user interface. All geoprocessing steps, including basin delineation and compilation of basin characteristics and water use within the basin, were completed in the Massachusetts StreamStats web application and exported for use by the Massachusetts Sustainable-Yield Estimator version 2.0.

\section{Introduction}

Water resources in Massachusetts are subject to many competing demands, including public water supply; industrial, agricultural, and recreational water uses; and environmental demands for aquatic habitat. To sustainably manage water resources for human and environmental needs, water regulators in Massachusetts need tools to estimate water availability in ungaged basins at a variety of spatial and temporal scales. Streamflow patterns depend on many natural physical basin characteristics, such as the climate, drainage area size, landscape features such as elevation or slope, and surficial geology of the drainage basin. Anthropogenic factors such as land use changes, impervious surfaces, dams, and water use (withdrawals and return flows) within the drainage basin also affect streamflow and can alter natural streamflow patterns.

The Massachusetts Sustainable-Yield Estimator (MA SYE) is a tool that estimates daily unaltered and wateruse-adjusted streamflow as well as the sustainable yield for an ungaged basin in Massachusetts (Archfield and others, 2010). 
In this report, unaltered streamflow refers to the estimated daily mean streamflow in a drainage basin in the absence of any water withdrawals or wastewater discharges and with minimal human development. The concept of the sustainable yield derives from the safe yield, which is defined for Massachusetts regulatory purposes as the maximum volume of water that can be continuously extracted from a water source during a period that includes the maximum probable drought (Massachusetts Water Management Act; General Court of the Commonwealth of Massachusetts, 1986). Archfield and others (2010) define the sustainable yield as the maximum amount of water that can be extracted from a drainage basin while still retaining a continuous minimum user-defined target streamflow.

The MA SYE version 1.0 (v1) methodology was developed by Archfield and others (2010) in cooperation with the Massachusetts Department of Environmental Protection and has since been incorporated into the Massachusetts Sustainable Water Management Initiative framework (Massachusetts Executive Office of Energy and Environmental Affairs, 2012), which is used to manage new and existing public water withdrawals in Massachusetts. Additionally, the MA SYE v1 has been used in subsequent studies to assess potential streamflow alteration across Massachusetts (Weiskel and others, 2010), to investigate the relation between streamflow alteration and fish populations (Armstrong and others, 2011), and to provide simulated inflows to reservoir models (Levin and others, 2011; Levin, 2016).

The sustainable yield is computed as the difference between the monthly unaltered streamflow and a user-defined minimum streamflow target, which may be based on regulatory or ecological instream flow criteria. To compute the sustainable yield, the MA SYE estimates mean unaltered daily flow at a basin of interest in Massachusetts from October 1, 1960, to September 30, 2004, using a combination of statistical methods. Daily streamflow is aggregated to generate monthly streamflow and subtracted from the minimum streamflow targets for each month to estimate the sustainable yield volume for the basin. Additionally, mean monthly reported water withdrawals and discharges for the basin are used to estimate daily water-use-adjusted streamflow. Wateruse information for the MA SYE was compiled from regulated surface-water and groundwater withdrawal and discharge sites. Water-use-adjusted flows can be compared with target streamflow to see the potential effects of current water usage on streamflow patterns and to determine if water use within the basin is exceeding the sustainable yield.

The MA SYE software application has been updated to improve functionality and stability. In this report, "MA SYE" refers to features and methods available in the original and new version of the software application, "MA SYE v1" refers to the original published version (Archfield and others, 2010), and "MA SYE v2" refers to the updates and functionality only in the new version. The MA SYE v1 software application required the user to have Esri ArcGIS (2008) software installed but was incompatible with ArcGIS release 10 (and later), limiting its functionality. In MA SYE v2, all geoprocessing steps have been incorporated into the Massachusetts StreamStats web application (U.S. Geological Survey, 2012), which enables users without ArcGIS software to use the application and will keep the software robust against future ArcGIS updates. Reported withdrawals and discharges in Massachusetts from 2010-15 have been incorporated into the StreamStats web application for use with the MA SYE v2. Geoprocessing steps done in StreamStats by the user for input into the MA SYE v2 include basin delineation, compilation of basin characteristics, and summarization of monthly average water use from regulated withdrawals and discharges within the basin.

This report describes updates to the methods and data used to estimate unaltered and water-use-adjusted streamflow at ungaged sites in Massachusetts and documents the release of the MA SYE v2 software. New features in the MA SYE v2 include a new user interface, updated water use from 2010 to 2015, and an option to output prediction intervals for monthly or daily unaltered streamflow time series.

\section{Methods for Estimating Unaltered Streamflow}

The MA SYE estimates daily unaltered streamflow at an ungaged basin from October 1, 1960, to September 30, 2004. Methods used by the MA SYE for computing the daily streamflow are described in detail by Archfield and others (2010) and are summarized here. The MA SYE uses a twostep process to first estimate the flow duration curve (FDC) at the ungaged site and then use a reference gage to reorder the FDC streamflow into a time series. In the first part of the process, the FDC for the ungaged basin is computed by using recursive regression equations to estimate streamflow at 17 exceedance probabilities. The MA SYE v2 uses the same regression equations that were originally developed by Archfield and others (2010) in the MA SYE v1. Of the 17 regression equations, 6 (those used to predict the 0.006-, 1-, 5-, 20-, 40-, and 80-percent exceedance probability flow) use basin characteristics as explanatory variables in the equations (table 1). The remaining 11 regression equations predict the streamflow quantiles at the 10-, 15-, 30-, 50-, 60-, 70-, 85-, 90-, 95-, 99-, and 99.994-percent exceedance probabilities using other regression-estimated streamflow quantiles (table 2). Regression coefficients for the 17 regression equations are listed in tables 1 and 2 . Regression equations were developed in logarithmic space and are all of the form:

$$
Y=e^{b_{o}} X_{1}^{b_{1}} X_{2}^{b_{2}} \ldots X_{n}^{b_{n}} B C F,
$$


Table 1. Explanatory variables and regression coefficients used to predict streamflow quantiles at ungaged, unaltered basins in the Massachusetts Sustainable Yield Estimator.

[Table modified from Archfield and others (2010). **, characteristics not included in regression equation]

\begin{tabular}{|c|c|c|c|c|c|c|}
\hline \multirow{2}{*}{ Regression explanatory variable } & \multicolumn{6}{|c|}{ Streamflow quantile exceedance probability } \\
\hline & $\mathbf{0}$ & 0.01 & 0.05 & 0.2 & 0.4 & 0.8 \\
\hline Constant term & 1.786 & -33.705 & -24.866 & 5.066 & 20.203 & 49.726 \\
\hline Drainage area & 0.820 & 0.938 & 0.978 & 0.994 & 1.031 & 1.048 \\
\hline Mean basin elevation & 0.451 & $* *$ & $* *$ & $* *$ & $* *$ & $* *$ \\
\hline Average annual precipitation & $* *$ & 2.539 & 2.129 & 0.949 & 0.75 & $* *$ \\
\hline Percentage of basin that is open water & $* *$ & $* *$ & $* *$ & $* *$ & -0.028 & $* *$ \\
\hline Percentage of basin that is wetlands & $* *$ & -0.091 & $* *$ & $* *$ & $* *$ & $* *$ \\
\hline $\begin{array}{l}\text { Percentage of basin that is underlain by } \\
\text { sand and gravel deposits }\end{array}$ & $* *$ & $* *$ & $* *$ & $* *$ & 0.036 & 0.151 \\
\hline Average maximum monthly temperature & $* *$ & $* *$ & $* *$ & $* *$ & $* *$ & -2.367 \\
\hline X-location of the basin outlet & $* *$ & $* *$ & $* *$ & 0.085 & 0.108 & $* *$ \\
\hline Y-location of the basin outlet & $* *$ & $* *$ & 1.345 & $* *$ & $* *$ & $* *$ \\
\hline Y-location of the basin centroid & $* *$ & 1.942 & $* *$ & -0.641 & -1.769 & -3.297 \\
\hline Bias correction factor & 1.030 & 1.010 & 1.002 & 1.003 & 1.004 & 1.031 \\
\hline
\end{tabular}

Table 2. Regression coefficients of recursive regression equations used to predict streamflows at 11 exceedance probabilities in the Massachusetts Sustainable Yield Estimator.

[Table modified from Archfield and others (2010). Qn, streamflow at the $n$-percent exceedance probability]

\begin{tabular}{ccccc}
\hline Exceedance probability & Regression constant & $\begin{array}{c}\text { Coefficient for } \\
\text { explanatory variable }\end{array}$ & Explanatory variable & Bias correction factor \\
\hline 0.10 & 0.228 & 0.993 & $Q 15$ & 1.003 \\
0.15 & 0.229 & 0.988 & $Q 20$ & 1.003 \\
0.30 & 0.345 & 0.986 & $Q 40$ & 1.004 \\
0.50 & -0.335 & 1.011 & $Q 40$ & 1.000 \\
0.60 & -0.367 & 1.01 & $Q 50$ & 0.999 \\
0.70 & -0.463 & 1.02 & $Q 60$ & 0.998 \\
0.85 & -0.346 & 1.03 & $Q 80$ & 0.999 \\
0.90 & -0.386 & 1.04 & $Q 85$ & 1.002 \\
0.95 & -0.492 & 1.06 & $Q 90$ & 1.002 \\
0.99 & -0.665 & 1.05 & $Q 95$ & 1.024 \\
1.00 & -1.525 & 1.204 & $Q 99$ & 1.026 \\
\hline
\end{tabular}


where

$\begin{array}{cc}e & \text { is the base of the natural logarithm; } \\ Y & \text { is streamflow, in cubic feet per second; } \\ X_{n} & \text { is the explanatory variable (either a basin } \\ & \text { characteristic or another estimated } \\ & \text { streamflow quantile; table 1); } \\ b_{n} & \text { is the regression-estimated coefficient for } \\ & \text { explanatory variable } X_{n} \text { (table 2); } \\ b_{0} & \text { is the regression-estimated constant term } \\ & \text { (table 2); and } \\ B C F & \begin{array}{c}\text { is a bias correlation factor used to reduce } \\ \text { bias in the predicted streamflow quantile } \\ \text { (table 2). }\end{array}\end{array}$

The second step in the streamflow estimation process transforms the flow duration curve quantiles into a time series by using a reference gage and the QPPQ method (Fennessey, 1994; Archfield and others, 2010). Streamflow quantiles at each exceedance probability along the estimated FDC are assigned the same date as the flows at that exceedance probability from the FDC of the reference gage. The MA SYE includes 66 potential reference gages in southern New England (fig. 1). Sites selected as reference gages in the MA SYE are unaltered and minimally altered (Armstrong and others, 2008). All reference gages have streamflow records from October 1, 1960, to September 2004. Where needed, gaged streamflow records were extended by using the MOVE.3 technique (Vogel and Stedinger, 1985) to obtain a common period of record. The success of the QPPQ method depends on using a reference gage that has a streamflow record that is highly correlated to the streamflow at the ungaged site. The MA SYE uses the map correlation method (Archfield and Vogel, 2010; Archfield and others, 2010) to estimate the correlation of each reference gage to the ungaged site by spatially interpolating the correlation of each pair of reference gages and then selects the reference gage with the highest predicted correlation between the reference gage and the ungaged site flows.

\section{Refinements of Previously Published Methods}

The methods used to estimate unaltered daily flows in the MA SYE v1 were largely unchanged for MA SYE v2; no changes were made to the regression equations, map correlation method, reference gage records, or QPPQ method. However, two minor changes were made to the interpolation method used to estimate the continuous FDC, which may result in unaltered streamflow estimates from the MA SYE v1 and MA SYE v2 differing slightly.

The first refinement to the continuous FDC estimation is the inclusion of measures to detect and correct estimated streamflow quantiles that result in non-monotonic FDCs. The recursive structure of the regression equations helps to ensure that estimated streamflow decreases with increasing exceedance probability. Recursive regression equations include a streamflow quantile as an explanatory variable, which ensures that the resulting estimated streamflow is ordered properly with respect to the explanatory streamflow quantile; however, including a single streamflow quantile as an explanatory variable does not ensure that the resulting estimated streamflow is properly ordered relative to other regression-estimated FDC quantiles.

The recursive regression equations for the 17 streamflow quantiles produce properly ordered FDCs for most locations in Massachusetts; however, there are instances where the process produces a non-monotonic FDC. A non-monotonic FDC can result from the regression equations because of differences in the relative sensitivity of the basin characteristics that are used as explanatory variables (table 1 ). For example, the regression coefficients for sand and gravel for the 80- and 40-percent exceedance probabilities are 0.151 and 0.036 , respectively. This means that, keeping all other basin characteristics equal, an increase in the percentage of sand and gravel will increase the estimated 80 -percent exceedance probability streamflow more than the estimated 40-percent exceedance probability streamflow (and by extension the estimated 70-percent exceedance probability streamflow, which is recursively derived from the 40-percent exceedance probability streamflow quantile). Similarly, the 80-percent exceedance probability streamflow is more sensitive to changes in Y-location of the basin and to temperature changes. Under certain circumstances, the difference in sensitivity can result in a predicted 80-percent exceedance probability streamflow that is greater than the predicted 70-percent exceedance probability streamflow.

To assess how frequently the regression equations produce non-monotonic FDCs in Massachusetts, the 17 regression equations were applied to 1,396 stream locations in Massachusetts that were previously studied by Weiskel and others (2010). The 1,396 stream locations, at which the regression equations were tested, are distributed in a spatially consistent manner throughout the State of Massachusetts and include the convergences of all second order or higher streams at locations where the MA SYE is valid (Brandt and Steeves, 2009). At 13 locations in the Housatonic, Farmington, and Hoosic River basins in western Massachusetts, the estimated streamflow at the 70-percent exceedance probability was less than the estimated streamflow at the 80-percent exceedance probability.

It is beyond the scope of this project to develop new streamflow quantile regressions for the MA SYE v2. Instead, quality-control procedures were added to the MA SYE v2 software to check the numerical consistency of the FDC at the ungaged basin. If a non-monotonic FDC is produced, the streamflow quantile from the regression equation causing the irregularity is removed and the daily FDC is re-interpolated without that data point. An example of a non-monotonic and corrected FDC is shown in figure 2.

The second refinement to previously published methods in the MA SYE v2 is in the interpolation method, which is used to produce the continuous FDC at an ungaged basin. In 


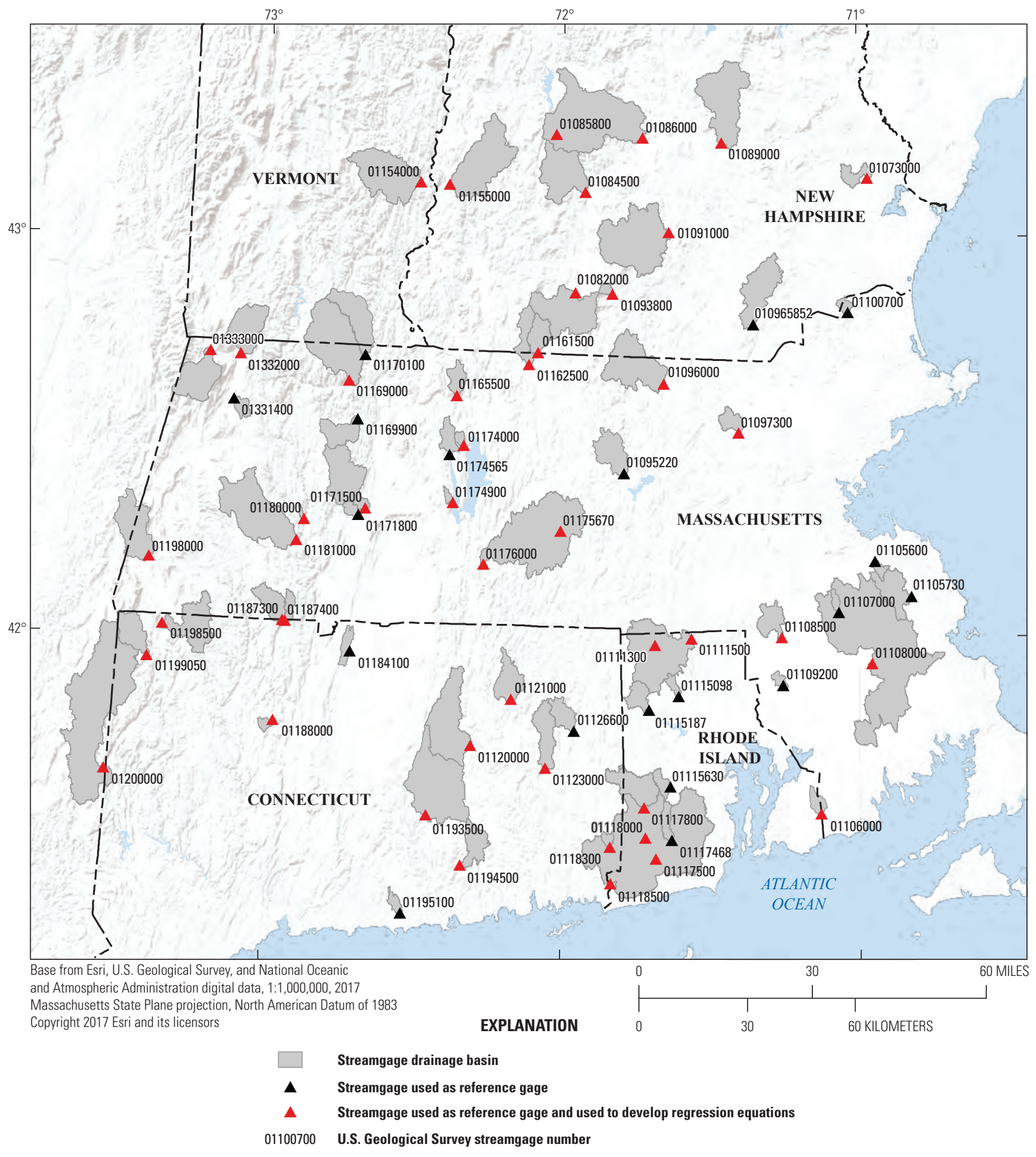

Figure 1. Reference gages used in the Massachusetts Sustainable-Yield Estimator development and application. 


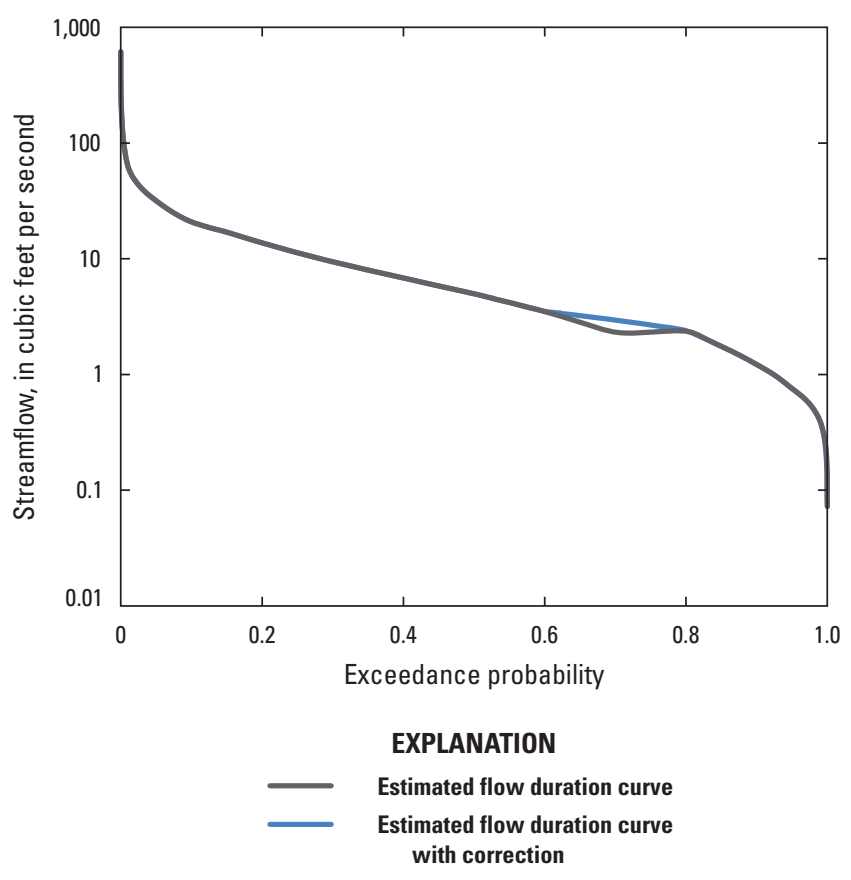

Figure 2. Streamflow estimated by the Massachusetts Sustainable Yield Estimator (MA SYE) for an ungaged basin that resulted in a non-monotonic flow duration curve and the correction added by the MA SYE version 2.0. the MA SYE v1, logarithm-linear interpolation was used to estimate the FDC between the regression-based streamflow quantiles. This interpolation assumes that the relation between the logarithm-transformed streamflow and the exceedance probabilities is linear. Although this assumption is valid across much of the FDC, more curvature is often seen at the extreme high and low ends of the FDC, and log-linear interpolation in these regions can cause the interpolated parts of the FDC to deviate from the shape of the gaged FDC. The MA SYE v2 transforms each exceedance probability of the FDC to a normal Z-score using equation 26.2.23 documented by Abramowitz and Stegun (1964) and linearly interpolates the logarithm-transformed streamflow quantiles from the regression equations across the Z-scores. The Z-scoretransformed interpolation has minimal effect on the middle parts of the FDC but matches the curvature of the high and low ends of the FDC better than the log-linear interpolation method (figs. $3 A$ and $B$ ). The plotting positions calculated by using the normal Z-score represent the spacing of adjacent points of the flow duration curve better than the linear exceedance percentiles. However, the differences in relative location of adjacent percentiles between the two methods are smaller near the center of the FDC than at the edges of the FDC (Haan, 1977; National Institute of Standards and Technology, 2012).
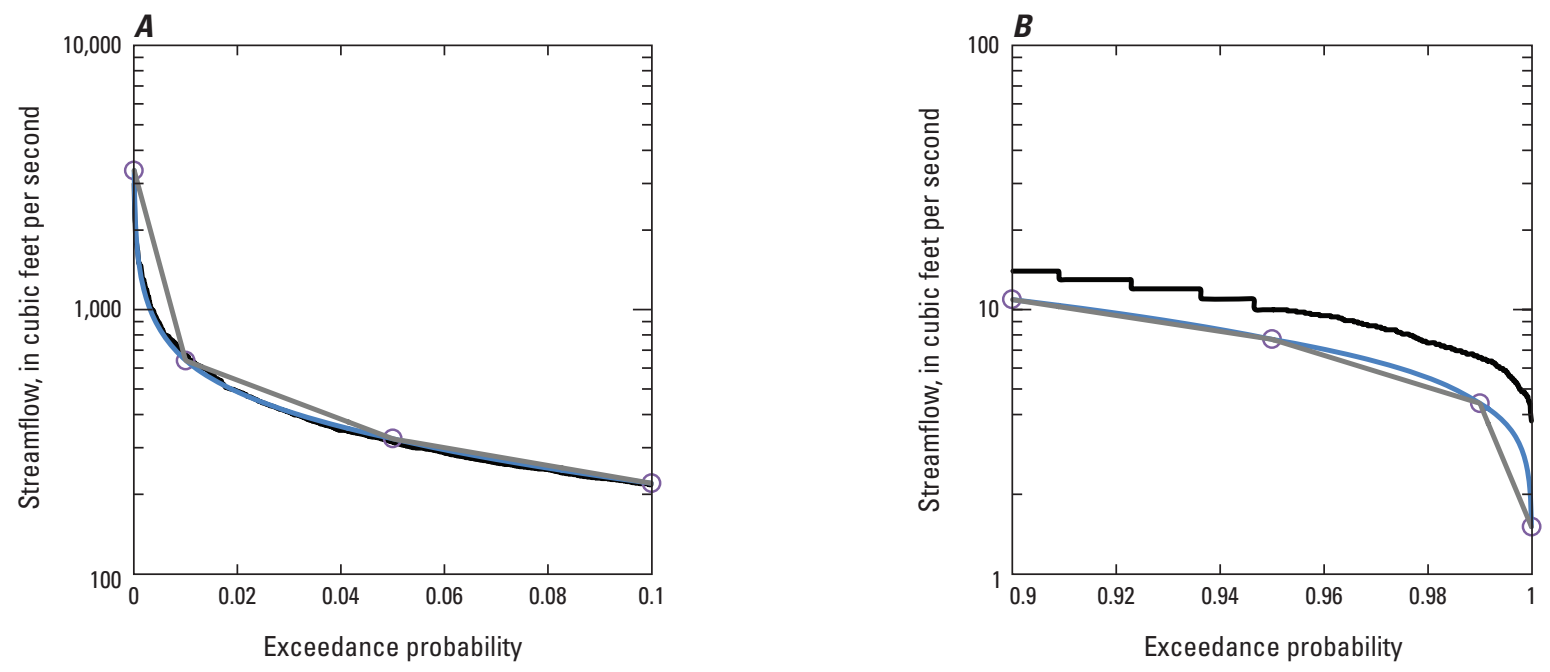

\section{EXPLANATION}

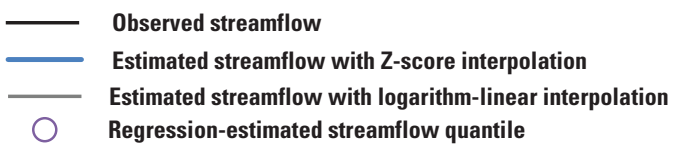

Figure 3. Gaged (observed) streamflows and estimated streamflows for $A$, the lower part and $B$, upper part of the estimated daily flow duration curve for U.S. Geological Survey streamgage 01171500, Mill River at Northampton, Massachusetts. 


\section{Uncertainty of Estimated Unaltered Streamflow}

There are two primary sources of uncertainty in the daily unaltered streamflow estimated by the MA SYE: (1) uncertainty in the regression equations and interpolation method used to construct the FDC and (2) uncertainty related to the selection and use of a reference gage in the QPPQ process used to construct a daily time series. The combination of uncertainty from both of these sources may cause estimated streamflow time series to deviate from gaged streamflow at an unaltered, minimally developed site. Archfield and others (2010) evaluated the accuracy of daily streamflow estimates using a remove-one cross validation at 18 reference gage sites and developed a model to predict the Nash-Sutcliffe efficiency, which is an indicator of overall goodness-of-fit of predicted streamflow across the entire period of record at an ungaged site. However, the MA SYE v1 lacked a method of estimating the uncertainty of individual daily streamflow estimates at an ungaged site.

A prediction interval for a daily streamflow defines the range of values that contains the actual daily streamflow at the ungaged location with a 95-percent probability. For example, if the prediction interval for a daily streamflow is 10 to 50 cubic feet per second, then there is a 95 -percent probability that the actual daily streamflow on that day was within that range. Note that prediction intervals differ from confidence intervals because they represent the uncertainty around a specific model prediction, not a population mean. Because the MA SYE uses a combination of numerical methods, standard methods of estimating prediction intervals are not applicable.

An empirical method to estimate prediction intervals for a streamflow time series estimated by a rainfall-runoff model was developed by Bourgin and others (2015) and modified for use in the MA SYE v2 (Farmer and Levin, 2017). The method used to estimate 95-percent prediction intervals in the MA SYE v2 assumes that the errors produced from simulations of reference gages that are most similar to the ungaged location have the same distributional properties as the simulation errors at the ungaged site. To implement the method, the regression equations used to estimate the FDC were redeveloped in a jackknife procedure, removing each reference gage used in the regression in turn and recomputing the regression equation coefficients. Reference gages most similar to the ungaged location are then simulated by using the jackknifed regression equations and the QPPQ process, and daily error ratios can be computed from the simulated and gaged time series. The error ratios from many such simulations are compiled and used to determine the probable error distribution for the ungaged site.

The process to construct prediction intervals for daily and monthly streamflow time series at an ungaged site is described below and illustrated in figure 4 .

1. Select five reference gages $\left(\mathrm{RG}_{n}\right.$ in fig. $\left.4 A\right)$ with the highest predicted correlation to the ungaged basin as predicted by the map correlation method. Streamflows at these reference gages are estimated by the MA SYE as if they were ungaged basins.

2. For each $\mathrm{RG}_{n}$, selected in step 1 , select the five reference gages $\left(\mathrm{RG}_{n, m}\right.$ in fig. $\left.4 B\right)$ that have a predicted correlation to the $\mathrm{RG}_{n}$ that is closest in value to the correlation between the ungaged basin and the reference gage used for the QPPQ method at the ungaged site.

3. Use regression equations from a remove-one cross validation to estimate the FDC at each $\mathrm{RG}_{n}$, and then apply the QPPQ method, using each $\mathrm{RG}_{n, m}$ to produce 5 estimated time series of streamflow at each of the $5 \mathrm{RG}_{n}$, for a total of 25 daily time series simulations (fig. $4 B$ ).

4. For each of the 25 simulated daily time series, compute the error ratio for each day as the observed and simulated streamflow for each day of the period of record, and group the error ratios by month (fig. $4 C$ ).

5. For each month, the 97.5- and 2.5-percentile error ratios are computed from the distribution of error ratios for that month (red dots in fig. 4C). Upper and lower prediction interval bounds for each daily streamflow at the ungaged basin are computed by multiplying simulated streamflow at the ungaged basin by the 97.5- and 2.5-percentile error ratios, respectively.

Farmer and Levin (2017) examined the reliability of empirical prediction intervals for daily streamflows estimated by the MA SYE by computing the coverage ratios of the intervals in a remove-one cross validation. The coverage ratio is the percentage of observations that fall within the prediction intervals across the entire period of record at a specific cross-validation site and is indicative of the nominal confidence level of the intervals. For example, 95-percent prediction intervals should have a coverage ratio of roughly 0.95 . If the coverage ratio at a validation location is greater than 0.95 , then the prediction interval includes the observed value with a greater probability than the stated 95 -percent, which indicates that the prediction interval is wider than is necessary and may over-estimate the uncertainty of the model prediction. Conversely, a coverage ratio lower than 0.95 at a validation location indicates that the prediction intervals at that location are too narrow and do not contain the observed value frequently enough.

To implement the cross validation, each of the MA SYE reference gages is removed in turn from the dataset, and all aspects of the simulation process, including regression equations and selection of the index gage used in the QPPQ method, are redeveloped without the gage in question. Then, streamflows and prediction intervals are computed at the removed gage. The cross validation removes any effect the simulated gage has on the development process, resulting in the simulation that would happen if the site was ungaged. Coverage ratios for prediction intervals of simulated daily streamflow at the MA SYE cross validation sites ranged from 0.8 to 1.0 with a median coverage ratio of 0.96 , indicating that 


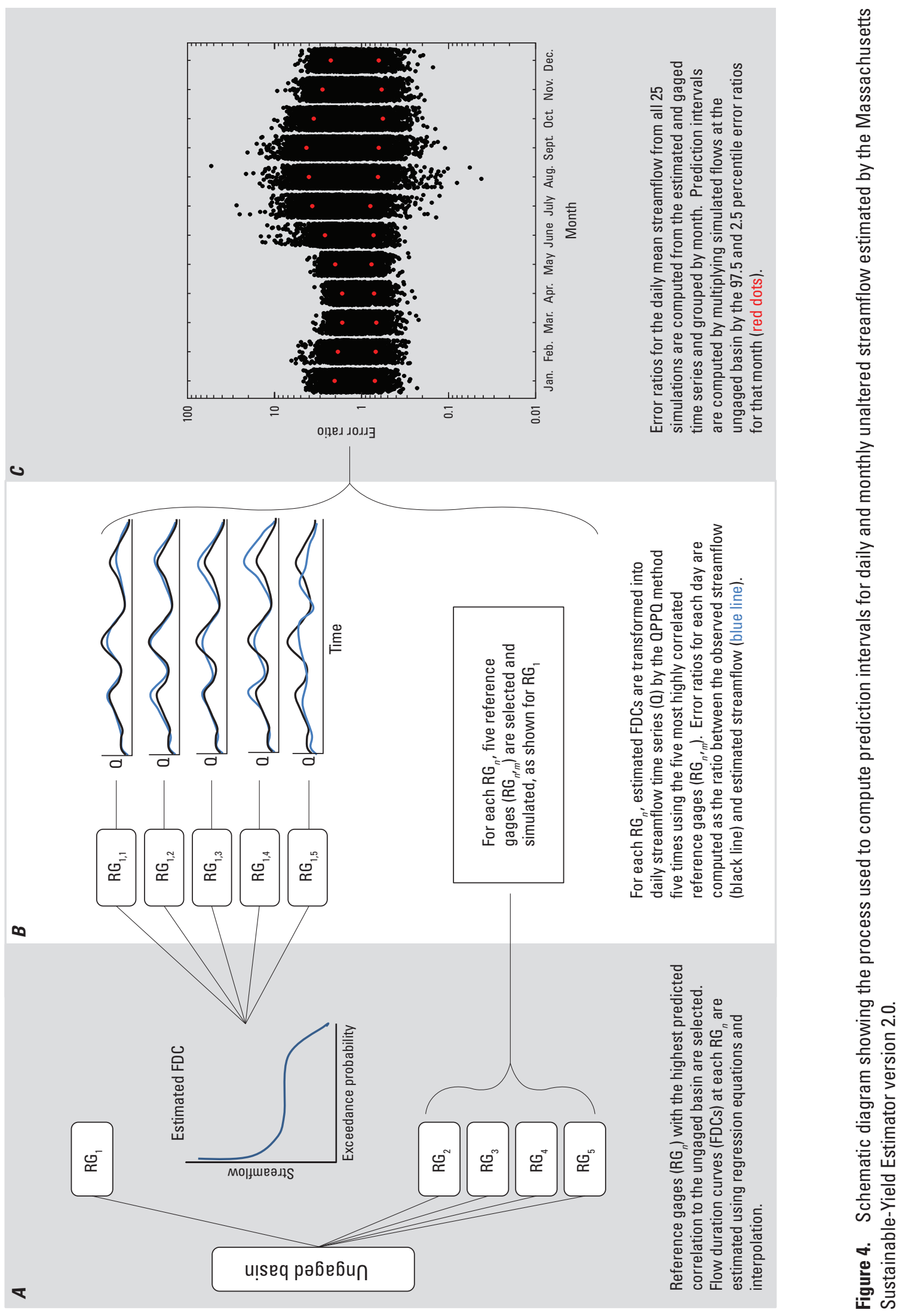


the method is adequate for providing reasonable uncertainty estimates at most locations (Farmer and Levin, 2017).

The MA SYE v2 computes prediction intervals for daily and monthly average time series for an ungaged site. Prediction intervals are interpreted as the range in which the true daily or monthly streamflow falls, with a 95-percent probability. Prediction intervals for monthly time series are computed by aggregating the daily streamflow time series to a monthly mean or median before completing steps 1 through 5 described previously in this section. The cross-validation procedure used by Farmer and Levin (2017) was repeated to evaluate the performance of prediction intervals for monthly streamflow estimates. Coverage ratios for monthly prediction intervals ranged from 0.78 to 1.0 with a median of 0.96 for monthly averages and from 0.72 to 1.0 with a median of 0.96 for monthly medians (fig. 5). Investigation into the performance and refinement of the prediction interval procedure is an area of ongoing research. For the MA SYE v2, the performance at most sites was adequate to provide the user with a reasonable measure of uncertainty in estimated daily and monthly unaltered streamflow values.

Daily streamflow time series estimated by the MA SYE are often aggregated for analysis or decision-making purposes. The MA SYE v2 reports the median of the monthly median streamflow, computed for each month as the median of the monthly medians from each year of the period of record. This metric has been used in other recent water availability and habitat studies in Massachusetts (Weiskel and others, 2010; Armstrong and others, 2011) and has been incorporated into the streamflow criteria of the 2014 Water Management Act regulations (Massachusetts Department of Environmental Protection, 2014). The accuracy of this highly aggregated metric computed by MA SYE has not been examined previously.

The accuracy of the median of monthly median unaltered streamflow computed by MA SYE v2 was assessed in a remove-one cross validation (described previously). The median of the monthly median was computed for observed and simulated streamflow at each of the 66 reference gages. In cases where record extension methods were used to obtain a common period of record (Archfield and others, 2010), only the gaged part of the period of record was used to compute the median of the monthly median streamflow. The median of the monthly median streamflow estimated by the MA SYE v2 had good agreement with observed values (fig. 6A). Percent error of the median of the monthly median of unaltered streamflow at the 66 reference gages typically was between -20 percent and 20 percent. Percent errors for July through September are more variable than other months and in general are larger because streamflow is lower during these months and a relatively small difference in streamflow may result in a larger percent error (fig. $6 B$ ).

Prediction intervals for the median of the monthly median flows are not computed by the MA SYE v2 because the method to compute empirical prediction intervals failed to produce accurate prediction intervals for the metric. Prediction intervals for the median of the monthly median

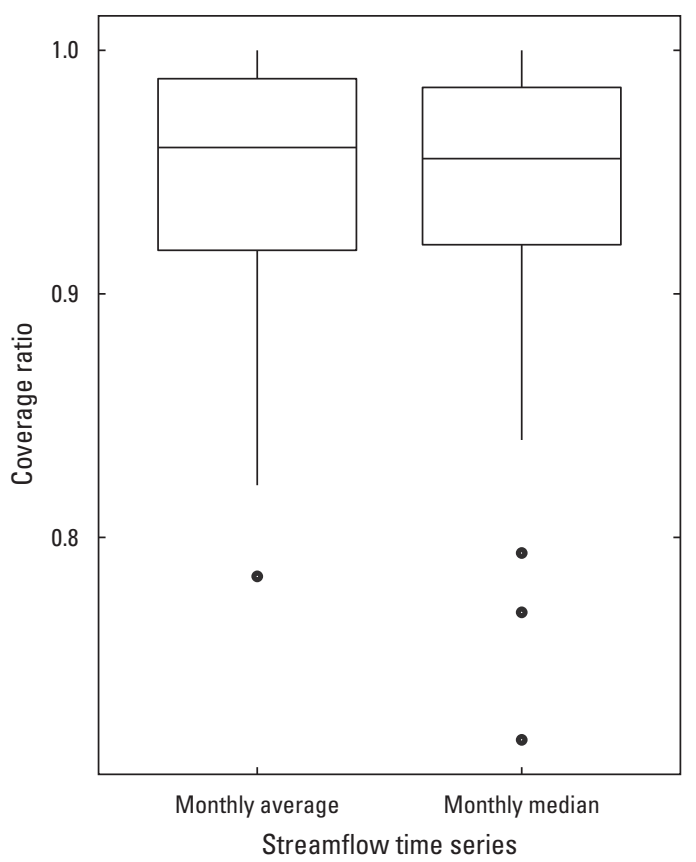

EXPLANATION

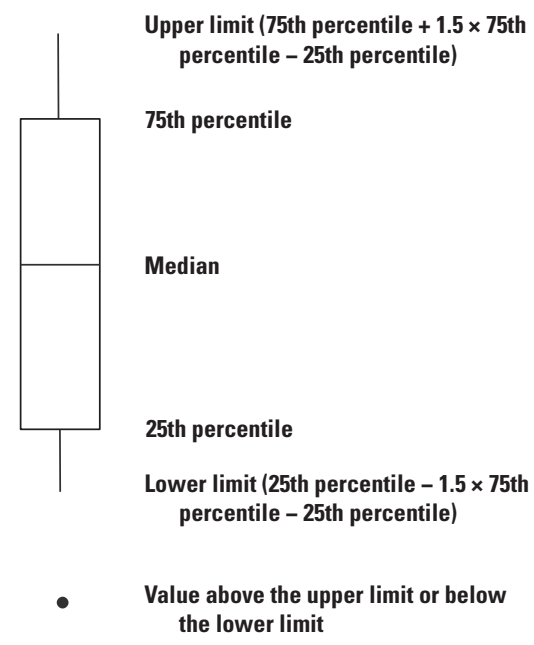

Figure 5. Coverage ratios for prediction intervals for monthly average and monthly median streamflow time series simulated by the Massachusetts SustainableYield Estimator version 2.0.

streamflow had coverage ratios below 0.90 at over half the validation sites, indicating that they are not able to represent the uncertainty of this metric reliably. This unreliability of the prediction intervals for this metric is likely due to the fact that because this is a highly aggregated metric, the sample distributions from which the confidence interval multipliers are derived (steps 3 and 4 above) have far fewer sample points from which to compute the 97.5 - and 2.5-percentile 


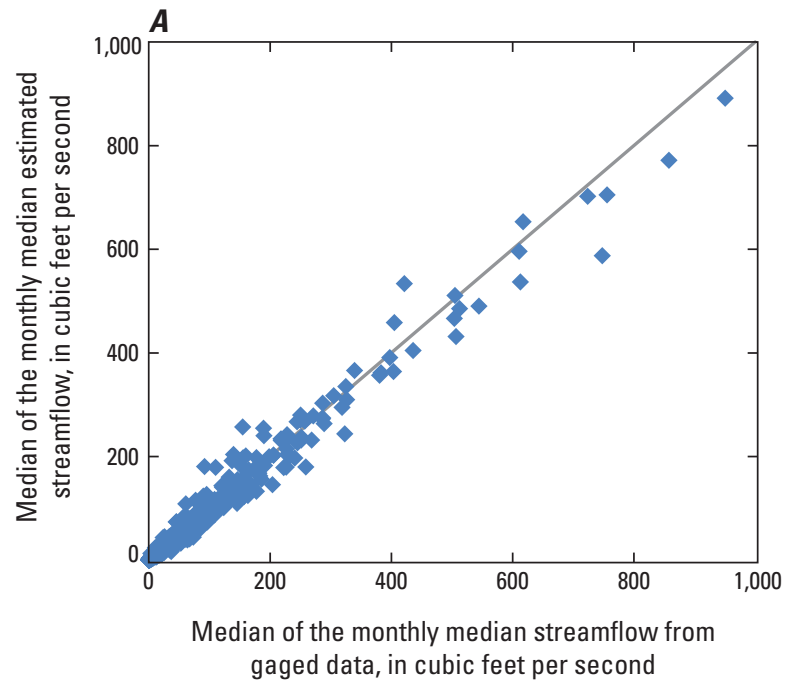

Figure 6. $A$, The median of the monthly median streamflow for estimated and gaged streamflow at 66 U.S. Geological Survey streamgages used as reference gages in the Massachusetts Sustainable-Yield Estimator version 2.0 and $B$, the percent error of estimates of median of the monthly median streamflow.

error ratios than when computing prediction intervals for daily or monthly time series. Because these percentiles are at the extreme ends of the error ratio distribution, they are sensitive to sample size (Brown and Wolfe, 1983). Research regarding methods of refining prediction interval estimation for highly aggregated streamflow metrics is ongoing.

\section{Estimation of Water-Use-Adjusted Daily Streamflow}

The MA SYE v2 uses water-use information from 4,425 withdrawals and discharges in Massachusetts from 2010 to 2014 to estimate water-use-adjusted daily streamflow.

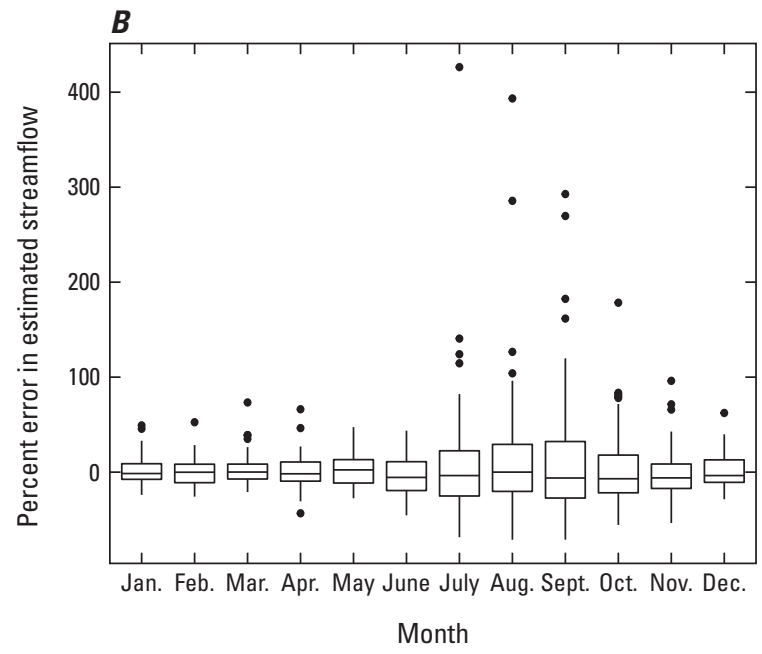

EXPLANATION

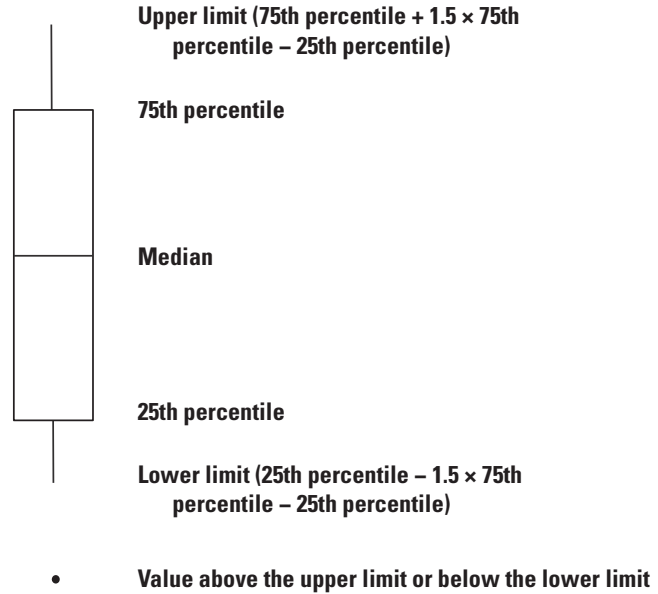

Water-use information was reported either as monthly or annual averages and was disaggregated to average daily rates. The water-use-adjusted streamflow time series is computed by adding the average daily discharges and subtracting average daily withdrawals for each source within the basin of interest from the daily unaltered streamflow. Average daily withdrawals and discharges from 2010 to 2014 are applied to the entire 44-year time series of unaltered streamflow.

The purpose of the water-use-adjusted streamflow time series is to compare current average water usage to the natural streamflow availability in the basin across a range of historical hydrologic conditions, including the drought of record. Water-use-adjusted streamflow is not intended to represent gaged streamflow. There are many reasons why water-useadjusted streamflow may not match gaged streamflow at a 
basin, including the following: (1) the water use applied in the computation of adjusted streamflow is an average and does not change from year to year, so it will not necessarily match the actual, reported water use of a particular year; (2) water-useadjusted streamflow does not account for upstream regulation from dams; and (3) adjusted streamflow does not take into account changes in the streamflow regime caused by land use changes or impervious surfaces.

Spatially referenced water withdrawal and wastewater discharge data within MA SYE v2 applicable areas were collected and provided by the Massachusetts Department of Environmental Protection and the U.S. Environmental Protection Agency for 2010 to 2014 (fig. 7). Reported wastewater discharge data included in the MA SYE v2 are monthly self-reported volumes at 413 groundwater locations with discharges greater than 10,000 gallons per day as regulated by the Massachusetts Department of Environmental Protection (2008) and 295 surface-water locations regulated by the U.S. Environmental Protection Agency National Pollutant Discharge Elimination permitting program. The MA SYE v2 also

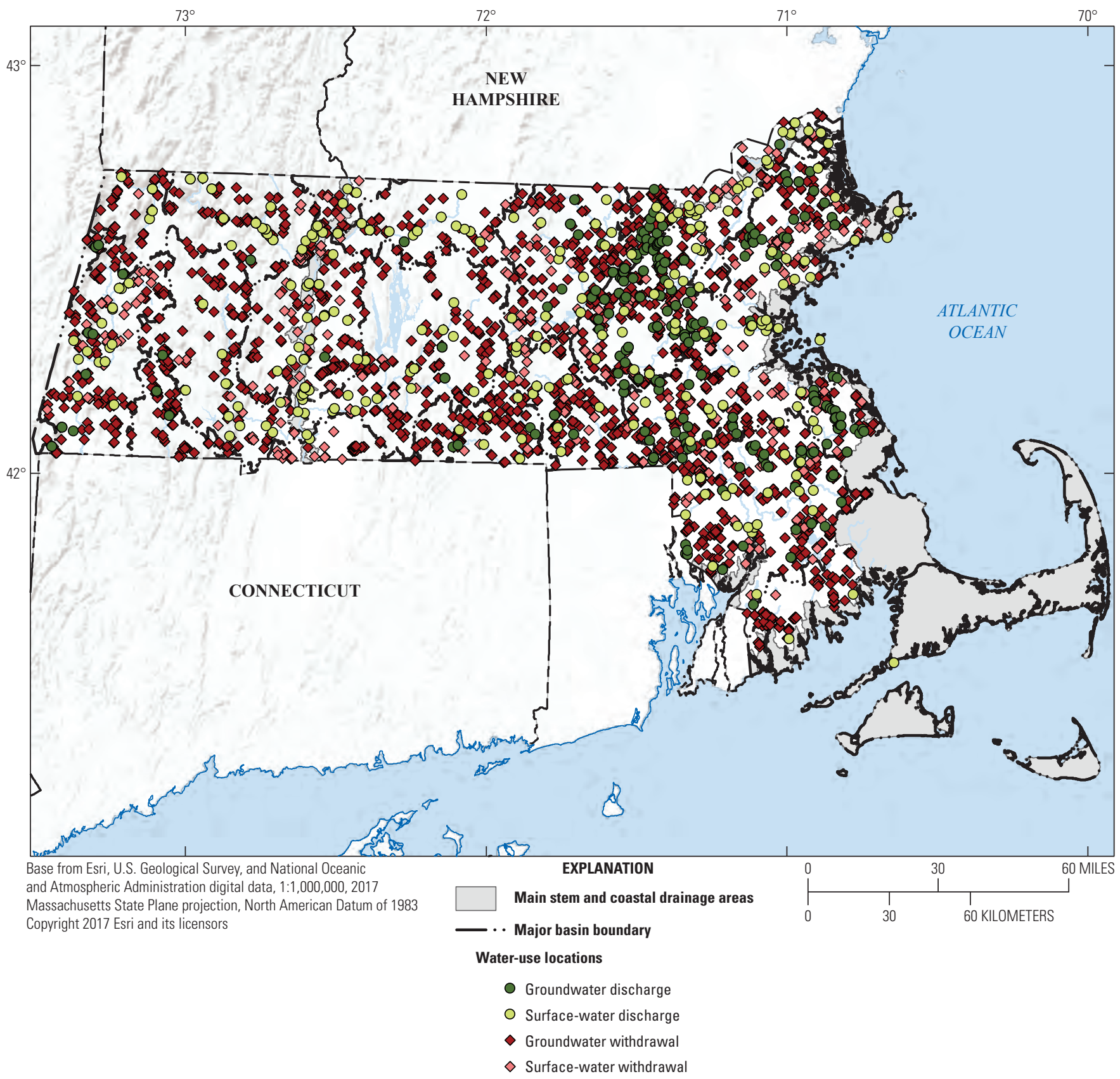

Figure 7. Groundwater and surface-water withdrawal and wastewater discharge locations used in the Massachusetts SustainableYield Estimator version 2.0 . 
includes monthly or annually self-reported water-use withdrawal volumes at 3,304 groundwater and 412 surface-water withdrawal locations. Reported withdrawals include (1) public water supply groundwater and surface-water withdrawals, including community, noncommunity, and transient facilities using less than 100,000 gallons per day; and (2) groundwater and surface-water withdrawals greater than 100,000 gallons per day as regulated by the Massachusetts Water Management Act (General Court of the Commonwealth of Massachusetts, 1986), including public and nonpublic water supplies (which include agricultural, golf course, commercial, or industrial water uses not for human consumption).

Water withdrawals regulated under the Water Management Act are reported as a system. A withdrawal system can contain one or more individual surface-water or groundwater withdrawal sources. Withdrawals under the Water Management Act are electronically recorded annually as the sum of all the groundwater and surface-water withdrawal sources within the system. To disaggregate the annual data into a monthly facility-level volume for each source, the annual system volume was divided equally among each source in the system, and then the annual data were disaggregated into monthly volumes on the basis of the water-use category. Monthly volumes are further disaggregated into average daily volumes on the basis of the number of days in each month. Monthly disaggregation curves were derived in cooperation with the Massachusetts Department of Environmental Protection (Richard Friend, written commun., 2016) for six nonpublic water supply water-use categories: golf, agricultural, ski resorts, nursery, hatcheries, and sand and gravel mining (fig. 8). Some Water Management Act systems may consist of public water supply withdrawals (which have source-level monthly reported volumes) and nonpublic water supply withdrawals. In these cases, the public water supply withdrawal volumes are subtracted from the system volume, and the remainder is divided among the nonpublic water supply sources.

Some categories of water use are not included in the MA SYE v2 database because of the lack of statewide reporting. Water-use data that are not represented in the database include nonpublic water supply withdrawals less than 100,000 gallons per day, such as low-volume withdrawals for irrigation, golf course, industrial, or commercial purposes. These water withdrawals are not reported to regulatory agencies because they are not public water supply sources and are below the Water Management Act regulating threshold. Domestic septic discharges and well withdrawals are not reported statewide and are not included in the MA SYE v2. Domestic water usage can be estimated by the population within the basin that uses septic and private wells. The user has the option to add this information for the basin of interest if known. Water used for cranberry cultivation also is not included in the MA SYE v2 data because this water typically is nonconsumptive. Water-use data for basins that extend into other States are not included in the database but may be added to a simulation by the user.
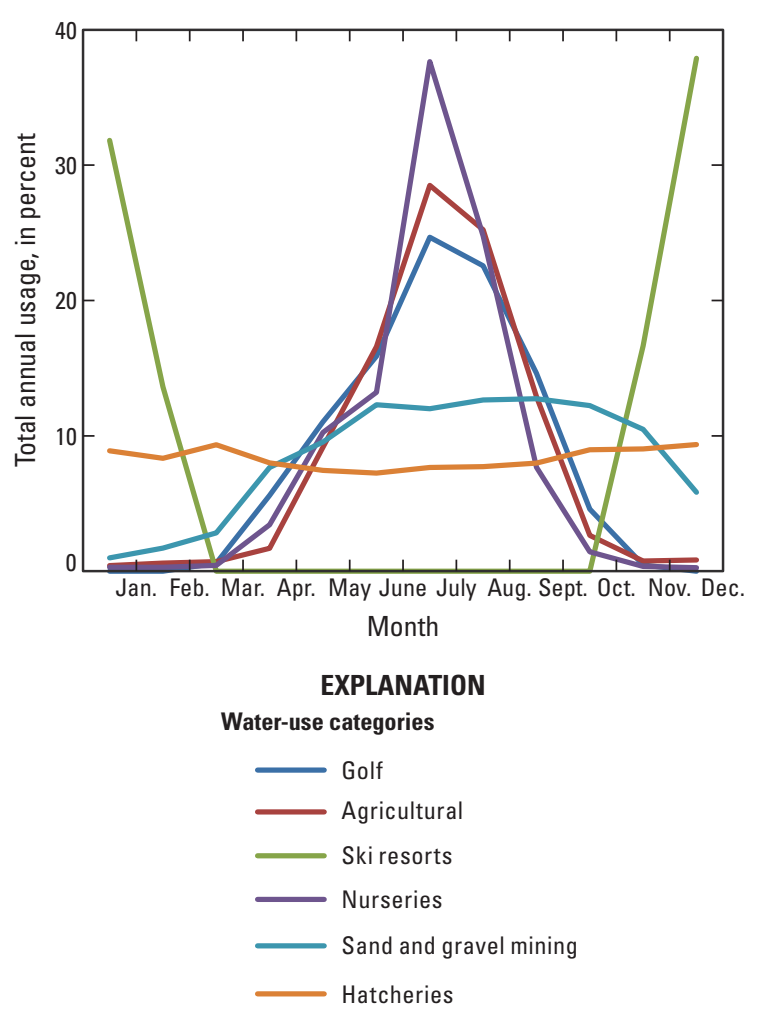

Figure 8. Average monthly water usage as a percentage of the annual total for six water-use categories used in the Massachusetts Sustainable-Yield Estimator version 2.0.

\section{Estimating Streamflow Alteration From Groundwater Withdrawals or Discharges}

The timing of streamflow alteration from a particular groundwater well or groundwater discharge source (such as a septic system) is often delayed from the time of pumping or discharge. The time-lagged response of a stream to groundwater usage in the basin is affected by the transmissivity of the aquifer and the distance of the groundwater source to the stream. The MA SYE v1 estimated the time-lagged streamflow alteration from groundwater sources using the STRMDEPL program (Barlow, 2000). The STRMDEPL program uses an idealized one-dimensional analytical equation to estimate time-lagged depletions from a groundwater well, so results may differ from calibrated three-dimensional groundwater flow models. Additionally, STRMDEPL provides a long-term simulated record of depletions that may not reach dynamic equilibrium (achieve mass balance between water-use volumes and changes in streamflows) for decades after the start of a simulation run, even when the initial conditions are set to long-term average pumping volumes. Because of the time needed to reach a dynamic equilibrium, STRMDEPL may provide unreliable streamflow depletion estimates during the lowest flows since these flows were at the beginning of the historical record used by the MA SYE v2. 
Because of the potential for STRMDEPL to provide unreliable groundwater alteration estimates, the method to estimate the time-lagged streamflow alteration from groundwater withdrawals in the MA SYE v2 has been updated to use algorithms developed for the U.S. Geological Survey Hydrologic Drought Decision Support System (HyDroDSS; Granato, 2014). Monthly groundwater response coefficients range from 0.0 to 1.0 and proportion each monthly water-use volume to the month of pumping and the 11 following months. For example, a response coefficient of 1.0 in the first month of pumping indicates that streamflow depletion in that month is equal to the volume of pumping. A response coefficient of 0.5 in the first month indicates that streamflow depletion in the first month of pumping is only 50 percent of the pumping volume for that month and that the rest of the pumping volume would cause depletions in subsequent months. Groundwater withdrawals cause reductions in evapotranspiration as well as reductions in streamflow, so the total depletions from groundwater withdrawals commonly are one or more percentage points smaller than the withdrawals (Barlow and Dickerman, 2001; DeSimone and others, 2002; Eggleston, 2004; Granato and Barlow, 2005; Bent and others, 2011; Barlow and Leake, 2012). Therefore, the final response-coefficient values for each groundwater site were adjusted so that they summed to 99.5 percent.

Because the effects of pumping may persist for several months after pumping, the streamflow depletion for a given month is equal to the depletions caused by the current month's pumping plus the continuing effects of the previous 11 months of pumping. The total streamflow depletion from a groundwater source for a given month is computed as

$$
Q s=\sum_{k=1}^{12} r_{k} Q w_{k},
$$

where

$$
\begin{gathered}
Q s \quad \begin{array}{c}
\text { is the streamflow depletion from a single } \\
\text { groundwater pumping site for a given } \\
\text { month, }
\end{array} \\
r_{k} \quad \begin{aligned}
\text { is the response coefficient for the pumping } \\
\text { site for month } k,
\end{aligned} \\
Q w_{k} \quad \begin{array}{l}
\text { is the average pumping rate for month } k \text {, and } \\
k \quad \text { is an index indicating the current month and } \\
11 \text { preceding months. }
\end{array}
\end{gathered}
$$

Total streamflow depletion for a given month is equal to the sum of depletions from all individual groundwater sources within the basin. Surface-water withdrawals are assigned a response coefficient of 1.0, which corresponds to an immediate alteration in streamflow with no persisting effect on streamflow in subsequent months.

Response-coefficient values were compiled from results of calibrated three-dimensional modular finite-difference groundwater-flow (MODFLOW) models for 108 groundwater sites documented in 7 U.S. Geological Survey modeling studies in Rhode Island and central and eastern Massachusetts (Barlow and Dickerman, 2001; DeSimone and others, 2002;
Eggleston, 2004; Granato and Barlow, 2005; Bent and others, 2011; Granato, 2014). The 12-month response-coefficient patterns were selected for each groundwater withdrawal or return flow site on the basis of the distance and diffusivity of each site. Groundwater sites that are close to a stream in high-transmissivity aquifers have a rapid altered-flow response. Sites that are distant from the stream or sites in lowtransmissivity aquifers have a slow altered-flow response. The 108 groundwater sites were classified into groups with similar transmissivities and stream distances, and average response coefficients from many wells were used to identify depletion patterns and select monthly response-coefficient values for each group. Default values for aquifer transmissivity were assigned to groundwater well locations in Massachusetts on the basis of previously published hydrologic atlases of Massachusetts watersheds. The shortest flow path from each groundwater well location to the nearest water body or stream within the basin was computed from digital elevation data (U.S. Geological Survey, 2017).

\section{Calculation of Sustainable Yield Using the Massachusetts Sustainable- Yield Estimator Version 2.0 Software Application}

A primary objective of this study was to update the MA SYE software application. The MA SYE v2 is built in Microsoft Access with a menu-driven graphical user interface that is designed to work in conjunction with the U.S. Geological Survey StreamStats web application (U.S. Geological Survey, 2012). All geoprocessing steps required by the MA SYE v2, including basin delineation, compilation of basin characteristics, and summarization of water use, are done by the user in StreamStats before running the MA SYE. Data are exported from StreamStats into the MA SYE v2 to compute daily streamflow time series. MA SYE v2 simulation results are summarized as either monthly means or the median of monthly medians for unaltered streamflow, water-use-adjusted streamflow, target streamflow, and sustainable yield. Users also may export daily and monthly streamflow time series. The MA SYE v2 software application and user manual (Granato and Levin, 2018a, b) are available at https://doi.org/10.5066/ P95VX5AX and https://doi.org/10.3133/ofr20181169, respectively.

\section{Limitations}

There are several limitations to the use of the MA SYE for estimating unaltered or water-use-adjusted streamflow. Regression equations used to estimate the flow duration curve at an ungaged site are based on reference gages with a limited 
set of basin characteristics. Flow duration curves and daily streamflow time series for ungaged sites whose basin characteristics are outside these ranges are uncertain, and prediction intervals for these sites may be unreliable. The MA SYE v2 tool provides warnings to the user when basin characteristics at a basin of interest have values outside of the range of the regression equations.

The MA SYE v2 is not applicable on the main stem of the Connecticut River or the Merrimack River. These large drainage basins are outside the range of drainage areas of the regression equations, and datasets needed to compute basin characteristics are not available in some upstream areas of these basins. Unaltered daily streamflow along the main stem of the Connecticut River can be estimated by using the Connecticut River Unimpacted Streamflow Estimation (CRUISE) Tool (Archfield and others, 2012), which can be accessed at https://newengland.water.usgs.gov/dev/s1/ctrtool/index.html. Additionally, the MA SYE assumes that groundwater and surface-water divides are coincident. This assumption is not valid on Cape Cod and some areas of southeastern Massachusetts, so the MA SYE is not suitable for use in these areas.

Water-use-adjusted streamflow estimates have several important limitations. Adjusted streamflow reflects mean reported monthly water usage from 2010 to 2014 and does not account for year-to-year variability or temporal changes in water-use patterns or water use from nonregulated wateruse categories. Additionally, it does not reflect changes in streamflow caused by other factors such as land use changes, impervious surfaces, or upstream dams or impoundments.

\section{Summary}

The Massachusetts Sustainable-Yield Estimator (MA SYE) estimates daily unaltered and water-use-adjusted streamflow at ungaged sites for October 1, 1960, to September 30, 2004, and computes the long-term sustainable yield for the basin. Sustainable yield is defined as the maximum volume of water that can be continuously extracted from a water source during a period that includes the maximum probable drought. Sustainable yield is computed by the MA SYE as the difference between mean monthly unaltered streamflow and a user-defined minimum monthly streamflow target. Methods for estimating daily unaltered streamflow were previously published and have been reproduced in version 2.0 (MA SYE v2) with minor changes and updated water-use data.

Daily unaltered streamflow is estimated by the MA SYE using a two-step process. First, a daily flow duration curve is estimated from previously published regression equations at 17 exceedance probabilities. Next, the QPPQ process is used to transform the flow duration curve (FDC) into a daily time series by using an appropriate reference gage. Streamflows at exceedance probabilities between the regression-based flows are obtained through interpolation. Interpolation methods in
MA SYE v2 were refined by converting the FDC exceedance probabilities to normal Z-scores before linear interpolation, which improved the curvature of the FDC at the extremes. Quality-control measures also were introduced, which detect and correct non-monotonic FDCs in the rare instances in which the regression equations produce them.

Estimates of daily unaltered streamflow are subject to uncertainty from several sources, including the regression equations and interpolation methods used to estimate the FDC and the selection and use of a reference gage to transform the FDC into a time series. An empirical method for estimating 95-percent prediction intervals for daily and monthly unaltered streamflow was implemented in MA SYE v2. Prediction intervals for daily and monthly time series had a median coverage ratio of 0.96 , indicating that the method is adequate for providing uncertainty estimates at the 95 -percent confidence level for most locations.

Aggregated metrics such as the median of monthly median streamflow are important for water regulators in Massachusetts. Empirical prediction intervals were unreliable for these highly aggregated streamflow metrics. A remove-one cross validation at 66 reference gages used in the MA SYE was done to assess the accuracy of the median of monthly median streamflow. Estimated median of the monthly median unaltered streamflow at the 66 reference gages had good agreement with observed values; percent errors typically were between -20 percent and 20 percent.

The MA SYE v2 computes water-use-adjusted streamflow using reported volumes from all regulated surface-water and groundwater withdrawals and discharges within the ungaged basin. Monthly water-use data from 2010 to 2014 were compiled. Water-use-adjusted streamflow is computed by subtracting average daily withdrawals and adding average daily discharges to the estimated unaltered streamflow time series. Time-lagged streamflow alterations from groundwater withdrawal or wastewater discharge sources are estimated by using a response-coefficient method developed from results of previously published, calibrated groundwater models in Massachusetts.

The MA SYE v2 software application was developed in Microsoft Access with a graphic user interface and is designed to be used in conjunction with the Massachusetts StreamStats web application. All geoprocessing steps, including basin delineation, computation of basin characteristics, and summarization of monthly water use are completed by the user in StreamStats before running the MA SYE v2. Data from StreamStats are imported into the MA SYE v2 desktop application to compute daily unaltered and water-useadjusted streamflow. Users can enter time-varying minimum target streamflow volumes that are subtracted from estimated unaltered streamflow to get the sustainable yield. Results from the MA SYE v2 are summarized by month, and all daily or monthly time series and prediction intervals can be exported by the user. 


\section{References Cited}

Abramowitz, M., and Stegun, I.A., eds., 1964, Handbook of mathematical functions with formulas, graphs, and mathematical tables: Washington, D.C., U.S. Department of Commerce, National Bureau of Standards, Applied Mathematics Series, v. 55, 1,046 p.

Archfield, S.A., Steeves, P.A., Guthrie, J.D., and Ries, K.G., III, 2012, Towards a publicly available, map-based regional software tool to estimate unaltered daily streamflow at ungauged rivers: Geoscientific Model Development, v. 6, p. 101-115. [Also available at https://doi.org/10.5194/ gmd-6-101-2013.]

Archfield, S.A., and Vogel, R.M., 2010, Map correlation method-Selection of a reference streamgage to estimate daily streamflow at ungaged catchments: Water Resources Research, v. 46, no. 10, 15 p. [Also available at https://doi.org/10.1029/2009WR008481.]

Archfield, S.A., Vogel, R.M., Steeves, P.A., Brandt, S.L., Weiskel, P.K., and Garabedian, S.P., 2010, The Massachusetts Sustainable-Yield Estimator-A decision-support tool to assess water availability at ungaged stream locations in Massachusetts: U.S. Geological Survey Scientific Investigations Report 2009-5227, 41 p., 1 CD-ROM. [Also available at https://doi.org/10.3133/sir20095227.]

Armstrong, D.S., Parker, G.W., and Richards, T.A., 2008, Characteristics and classification of least altered streamflows in Massachusetts: U.S. Geological Survey Scientific Investigations Report 2007-5291, 113 p., 1 CD-ROM.

Armstrong, D.S., Richards, T.A., and Levin, S.B., 2011, Factors influencing riverine fish assemblages in Massachusetts: U.S. Geological Survey Scientific Investigations Report 2011-5193, 59 p. [Also available at https://doi.org/10.3133/ sir20115193.]

Barlow, P.M., 2000, Documentation of computer program STRMDEPL - A program to calculate streamflow depletion by wells using analytical solutions, in Zarriello, P.J., and Ries, K.G., III, A precipitation runoff model for analysis of the effects of water withdrawals on streamflow, Ipswich River Basin, Massachusetts: U.S. Geological Survey WaterResources Investigations Report 00-4029, p. 77-89. [Also available at https://doi.org/10.3133/wri004029.]

Barlow, P.M., and Dickerman, D.C., 2001, Numerical-simulation and conjunctive-management models of the HuntAnnaquatucket-Pettaquamscutt stream-aquifer system, Rhode Island: U.S. Geological Survey Professional Paper 1636, 88 p. [Also available at https://doi.org/10.3133/ pp1636.]
Barlow, P.M., and Leake, S.A., 2012, Streamflow depletion by wells-Understanding and managing the effects of groundwater pumping on streamflow: U.S. Geological Survey Circular 1376, 84 p. [Also available at https://doi.org/10.3133/ cir1376.]

Bent, G.C., Zarriello, P.J., Granato, G.E., Masterson, J.P., Walter, D.A., Waite, A.M., and Church, P.E., 2011, Simulated effects of water withdrawals and land-use changes on streamflows and groundwater levels in the Pawcatuck River Basin, southwestern Rhode Island and southeastern Connecticut: U.S. Geological Survey Scientific Investigations Report 2009-5127, 254 p. [Also available at https://doi.org/10.3133/sir20095127.]

Bourgin, F., Andréassian, V., Perrin, C., and Oudin, L., 2015, Transferring global uncertainty estimates from gauged to ungauged catchments: Hydrology and Earth System Sciences, v. 19, no. 5, p. 2535-2546. [Also available at https://doi.org/10.5194/hess-19-2535-2015.]

Brandt, S.L., and Steeves, P.A., 2009, Local and cumulative impervious cover of Massachusetts stream basins: U.S. Geological Survey Data Series 451. [Also available at https://pubs.er.usgs.gov/publication/ds451.]

Brown, M.B., and Wolfe, R.A., 1983, Estimation of the variance of percentile estimates: Computational Statistics \& Data Analysis, v. 1, p. 167-174. [Also available at https://doi.org/10.1016/0167-9473(83)90088-9.]

DeSimone, L.A., Walter, D.A., Eggleston, J.R., and Nimiroski, M.T., 2002, Simulation of ground-water flow and evaluation of water-management alternatives in the Upper Charles River Basin, eastern Massachusetts: U.S. Geological Survey Water-Resources Investigations Report 02-4234, 94 p. [Also available at https://doi.org/10.3133/wri024234.]

Eggleston, J.R., 2004, Evaluation of strategies for balancing water use and streamflow reductions in the Upper Charles River Basin, Eastern Massachusetts: U.S. Geological WaterResources Investigations Report 03-4330, 94 p. [Also available at https://doi.org/10.3133/wri034330.]

Esri, 2008, ArcGIS 10.3.1: Esri software, accessed at http://www.esri.com/software/arcgis.

Farmer, W.H., and Levin, S., 2017, Characterizing uncertainty in daily streamflow estimates at ungauged locations for the Massachusetts Sustainable Yield Estimator: Journal of the American Water Resources Association, v. 53, no. 6, p. 198-210. [Also available at https://doi.org/10.1111/1752-1688.12603.]

Fennessey, N.M., 1994, A hydro-climatological model of daily streamflow for the northeast United States: Medford, Mass., Tufts University, Ph.D. dissertation [variously paged]. 
General Court of the Commonwealth of Massachusetts, 1986, Massachusetts Water Management Act: General Court of the Commonwealth of Massachusetts, General Laws, part I, title II, chap. $21 \mathrm{G}$, accessed June 2016 at https://malegislature.gov/Laws/GeneralLaws/PartI/TitleII/ Chapter21G.

Granato, G.E., 2014, Hydrologic Drought Decision Support System (HyDroDSS): U.S. Geological Survey Open-File Report 2014-1003, 91 p., 1 CD-ROM. [Also available at http://dx.doi.org/10.3133/ofr20141003.]

Granato, G.E., and Barlow, P.M., 2005, Effects of alternative instream-flow criteria and water-supply demands on ground-water development options in the Big River Area, Rhode Island: U.S. Geological Survey Scientific Investigations Report 2004-5301, 110 p. [Also available at https://doi.org/10.3133/sir20045301.]

Granato, G.E., and Levin, S.B., 2018a, Massachusetts Sustainable-Yield Estimator (MA SYE) application software (ver. 2.0, November 2018): U.S. Geological Survey software release, https://doi.org/10.5066/P95VX5AX.

Granato, G.E., and Levin, S.B., 2018b, User guide for the Massachusetts Sustainable-Yield Estimator (MA SYEversion 2.0) computer program: U.S. Geological Survey Open-File Report 2018-1169, 7 p., https://doi.org/10.3133/ ofr20181169.

Haan, C.T., 1977, Statistical methods in hydrology: Ames, Iowa, Iowa State University Press, 378 p.

Levin, S.B., 2016, Effects of water-supply reservoirs on streamflow in Massachusetts: U.S. Geological Survey Scientific Investigations Report 2016-5123, 35 p. [Also available at https://doi.org/10.3133/sir20165123.]

Levin, S.B., Archfield, S.A., and Massey, A.J., 2011, Refinement and evaluation of the Massachusetts firm-yield estimator model version 2.0: U.S. Geological Survey Scientific Investigations Report 2011-5125, 49 p., 1 CD-ROM. [Also available at https://doi.org/10.3133/sir20115125.]
Massachusetts Department of Environmental Protection, 2008, Administrative penalty regulations: Massachusetts Register, 310 CMR 5.00, accessed June 2016 at https://www.mass.gov/regulations/310-CMR-500-administrative-penalty-regulations.

Massachusetts Department of Environmental Protection, 2014, Massachusetts water resources management program: Massachusetts Register, 310 CMR 36.00, accessed June 2016 at https://www.mass.gov/regulations/310-CMR-3600-massachusetts-water-resources-management-program.

Massachusetts Executive Office of Energy and Environmental Affairs, 2012, Sustainable Water Management Initiative: Commonwealth of Massachusetts web page, accessed September 2018 at https://www.mass.gov/service-details/ sustainable-water-management-initiative.

National Institute of Standards and Technology, 2012, NIST/ SEMATECH e-handbook of statistical methods: National Institute of Standards and Technology, accessed May 1, 2017, at https://www.itl.nist.gov/div898/handbook/.

U.S. Geological Survey, 2012, The StreamStats program for Massachusetts: U.S. Geological Survey web application, accessed June 2017 at https://streamstats.usgs.gov/ss/.

U.S. Geological Survey, 2017, Welcome to StreamStats: U.S. Geological Survey web page, accessed March 17, 2017, at https://water.usgs.gov/osw/streamstats/.

Vogel, R.M., and Stedinger, J.R., 1985, Minimum variance streamflow record augmentation procedures: Water Resources Research, v. 21, no. 5, p. 715-723. [Also available at https://doi.org/10.1029/WR021i005p00715.]

Weiskel, P.K., Brandt, S.L., DeSimone, L.A., Ostiguy, L.J., and Archfield, S.A., 2010, Indicators of streamflow alteration, habitat fragmentation, impervious cover, and water quality for Massachusetts stream basins: U.S. Geological Survey Scientific Investigations Report 2009-5272, 70 p., 1 CD-ROM. [Also available at https://doi.org/10.3133/ sir20095272.] 
For more information about this report, contact: Director, New England Water Science Center U.S. Geological Survey

10 Bearfoot Road

Northborough, MA 01532

dc_nweng@usgs.gov

or visit our website at

https://newengland.water.usgs.gov

Publishing support provided by the

Pembroke and Rolla Publishing Service Centers 


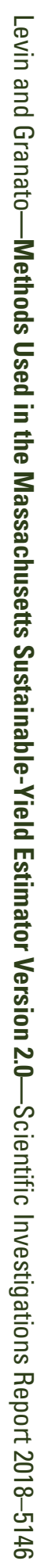

